\title{
ENHANCING SALT TOLERANCE OF WHEAT PLANT \\ (TRITICUM AESTIVUM L.) BY APPLICATION OF \\ PROLINE, ASCORBIC ACID, ARGININE, GLUTAMINE \\ AND GLUTATHIONE
}

\author{
El-Kassas, H. I. ${ }^{(1)}$; Abdalla, Kh. S..$^{(2)}$ and Ahmed, Shaimaa ${ }^{(2)}$ \\ 1) Environmental Studies and Research Institute, Ain Shams University \\ 2) Agricultural Genetic Engineering Research Institute, Agricultural Research \\ Center.
}

\begin{abstract}
Salinity is becoming nowadays one of the major abiotic stress issues worldwide. Wheat is considered as moderately salt tolerant crop and is adversely affected in response to the salt stress in terms of growth and yield. Pot experiment was conducted to determine the effect of exogenous proline, ascorbic acid, arginine, glutamine and glutathione application on some growth and biochemical parameters of wheat grown under salt stress conditions. The experiment was conducted under field conditions of wheat (Triticum aestivum L.) cultivar sakha 93. Three replicates, five grains per replicate were sown directly in plastic pots. Wheat plants were treated with $100 \mathrm{mg} / \mathrm{l}$ proline, 88 $\mathrm{mg} / \mathrm{l}$ ascorbic acid, $100 \mathrm{mg} / \mathrm{l}$ arginine, $10 \mathrm{mg} / \mathrm{l}$ glutamine and $50 \mathrm{mg} / \mathrm{l}$ glutathione. Salinity treatments were established by adding 6000, 8000 and $10000 \mathrm{mg} / \mathrm{l}$ of sea salt. The results obtained from this experiment revealed that growth parameters such as shoot length, root weight and grain weight, in addition to biochemical compounds such as chlorophyll, starch, fiber, ash and fat were affected by both salt and treatments. These parameters were decreased in response to salinity stress compared to untreated plants. The decrement in the growth parameters and biochemical compounds were found to be increased with increasing salt concentrations, particularly at $6000 \mathrm{mg} / \mathrm{l}$, $8000 \mathrm{mg} / \mathrm{l}$ and $10000 \mathrm{mg} / \mathrm{l}$ respectively. The selected compounds mitigate the negative effects of salt stress and improved growth parameters and
\end{abstract}


biochemical compounds compared with control plants under different salinity level.

Key words: abiotic stress, salt stress, salinity tolerance and wheat plant.

\section{INTRODUCION}

Salinity are major abiotic stress which leads to increasing yield losses in crops all over the world (Fulda et al., 2011). High salinity is one of the most widespread abiotic stress factors in agriculture, causing problems in plant production both on naturally saline soils and on irrigated lands with unsuitable water management or exposure to high evaporation. Depending on the level of the stress and the stage of plant development, high salinity may induce various physiological malfunctions (Hossain et al., 2015; Kranner and Seal, 2013). Salt stress, like many a biotic stress factors, reduces the ability of plants to take up water, leading to growth reduction as well as metabolic changes similar to those caused by the water stress (Munns, 2002). High salt concentration in root affects the growth and yield of many important crops (Taffouo et al., 2004). The salinity may reduce the crop yield by upsetting water and nutritional balance of plant (Khan et al., 2007; Taffouo et al., 2009).

One of the biochemical changes occurring when plants are subjected to these harmful stress conditions such as salinity is the accumulation of reactive oxygen species (ROS) such as superoxide $\left(\mathrm{O}^{-2}\right)$, hydrogen peroxide $\left(\mathrm{H}_{2} \mathrm{O}_{2}\right)$ and hydroxyl radicals $(\mathrm{OH})$ (Xue and Liu, 2008). These ROS attack lipids, proteins and nucleic acids, causing lipid peroxidation, protein denaturing and DNA mutation. Plants possess several anti-oxidants enzyme systems that 
protect their cells from the negative effects of ROS. Also reactive oxygen species cause chlorophyll degradation and damage the cellular components (Wang et al., 2009; Van Breusegem and Dat, 2006; Verma and Mishra, 2005).

Salinity tolerance is defined as the ability of plants to continuously grow under salt stress conditions (Munns, 2002). This makes the uptake mechanisms and accumulation pattern of ions in different plant organs important factors to determine salt tolerance (Ashraf and Ahmad, 2000). Another major factor of salt tolerance mechanisms is the ability of plant cells to adjust osmotically and to accumulate organic solutes (proteins, sugar, amino acids, etc.). The accumulation of these compounds is not only important for cell osmo-regulation but also for the protection of subcellular structures (Munns, 2002) and maintenance of protein structures (Silveira et al., 2001).

In response to salinity, plants have developed several strategies to cope with these challenges. One of the stress defense mechanisms is the antioxidant defense system, which includes antioxidants and antioxidant enzymes (Wang et al., 2009). These include $\beta$-carotenes, ascorbate, $\alpha$ tocopherol ( $\alpha$-toc), reduced glutathione (GSH) and enzymes including superoxide dismutase (SOD), peroxidase (POD), ascorbate peroxidase (APX), catalase (CAT), polyphenol oxidase (PPO) and glutathione reductase (GR) (Jaleel et al., 2009). Most of the studies showed that increase in activity of SOD, APX, GR, CAT and POX in response to oxidative stress such as salt (Türkan et al., 2005; Yasar et al., 2006; Kusvuran et al., 2012). 
Wheat is the third largest cereal produced in the world and it supplies over $20 \%$ of calories in human food around the globe. Wheat production and productivity directly influence human survival in developing countries and quality of life in industrial countries (Shahzad et al., 2013). Wheat is next to rice as a main source of food for consumers of developing countries and it is primary source of proteins (Braun et al., 2010).

Mass and Hoffman (1977) in their classical work on salt tolerance classification had declared wheat (Triticum aestivum L.) as a moderately salt tolerant crop. Several approaches have been proposed to improve salt tolerance of wheat by introducing genes for salt tolerance into adapted cultivars (Munns, 2005), screening of large germplasm collections (Shahzad et al., 2012), detailed field trials of selected cultivars (Munir et al., 2011), conventional breeding methods (Salam et al., 1999) and unconventional crosses with wild relatives (Colmer et al., 2006).

Another approaches to improve salt tolerance in plants by application of some compounds. Exogenous amino acids have been shown to promote potassium and calcium uptake. Exogenous application of proline is known to induce abiotic stress tolerance in plants (Claussen, 2005). The most studied compound under salinity stress is proline. The amount of proline usually increases under salinity (Khatkar and Kuhad, 2000). Exogenous application of proline can play an important role in enhancing plant stress tolerance. This role can be in the form of either osmoprotection or cryoprotection (Ashraf and Foolad, 2007; Giri, 2011). Exogenous application of amino acids may reduce salt induced adverse effects and results in a significant increment of 
growth and yield (Salama, 2009). Some experimental studies have shown that exogenous application of amino acids stimulates the germination percentage and early seedling growth of wheat (Afzal et al., 2006; Kürşat and Göksel, 2015). The role of arginine in plant stress response has been reported (Zeid, 2009; Nasibi et al., 2011; Zheng et al., 2011). Also, glutathione (GSH) is considered the most important redox buffer of the cell during plant stress (Elie et al., 2014).

The aim of the present study was to evaluate the response of wheat plant growth under salinity conditions and to study the role of proline, ascorbic acid, arginine, glutamine and glutathione in alleviating the harmful effects of salinity stress.

\section{MATERIALS AND METHODS}

Cultivation of wheat plant and treatment: Wheat plant cultivation was performed according to Tottman and Broad (1987). The experiment was conducted in Agricultural Genetic Engineering Research Institute (AGERI), Agricultural Research Center (ARC) Egypt. The experiment was conducted at field conditions during wheat seasons from November to the end of April, seasons 2012/2013 and 2013/2014. The grains were sown in plastic pots (30 $\mathrm{cm}$ diameter and $25 \mathrm{~cm}$ depth), each containing black soil, sand and peatmoss mixture in equal ratios (see Tables 1 and 2 for soil analysis) with ten seeds per pot, in three replicates for each treatment. All pots were watered with half-strength Hoagland's nutrient solution during the experiment. After germination, unwanted seedlings were removed to insure that there were 5 seedlings in each pot. Plants of similar size were divided into three groups as 
follow: group one as a control, irrigated with tap water. Group two, subdivided into three sets, Each set treated with salt solution 6000, 8000 and $1000 \mathrm{mg} / \mathrm{l}$. Group three subdivided into three sets, treated with salt solution as group two plus the addition of proline $(100 \mathrm{mg} / \mathrm{l})$, ascorbic acid $(88 \mathrm{mg} / \mathrm{l})$, arginine $(100 \mathrm{mg} / \mathrm{l})$, glutathione $(50 \mathrm{mg} / \mathrm{l})$ and glutamine $(10 \mathrm{mg} / \mathrm{l})$ for each salt concentration. Treatments of groups two and three were started when three leaves were fully expanded for each plant. The sea salt was prepared by dissolving the salt in distilled water at 6000, 8000 and $1000 \mathrm{mg} / \mathrm{l}$ (the major ions of sea water were: $487 \mathrm{mM} \mathrm{Na}^{+}, 10 \mathrm{mM} \mathrm{K}^{+}, 54 \mathrm{mM} \mathrm{Mg}^{2+}, 586 \mathrm{mM} \mathrm{Cl}$, plus other less concentrated macro- and micro-nutrients). Leave tissue samples of treated and control plants were extracted for the evaluation of some antioxidant enzymes such as ascorbate peroxidase, peroxidase and catalase after two weeks of salt application. Dry root weight and shoot length were recorded after two months of sowing, while grains weight and biochemical analysis including total chlorophyll, total carbohydrate, starch, total protein, fiber, ash and fat content were recorded at the end of seasons (after four months of sowing).

Table 1. Chemical analysis of soil sample for wheat plant

\begin{tabular}{|c|c|c|c|c|c|c|c|c|c|}
\hline O.M & pH & EC. & \multicolumn{4}{|c|}{$\overline{~ C a t i o n s ~ m e q . L ~}^{-1}$} & \multicolumn{3}{|c|}{ Anions meq. L $^{-1}$} \\
\hline & & & $\mathbf{N a}^{+}$ & $\mathbf{K}^{+}$ & $\mathrm{Ca}^{2+}$ & $\mathrm{Mg}^{2+}$ & $\mathrm{Cl}^{-}$ & $\mathrm{CO}_{3}{ }^{2-}$ & $\mathrm{HCO}_{3}^{-}$ \\
\hline 2.91 & 7.07 & 2.30 & 6.35 & 1.44 & 13.92 & 1.30 & 2.485 & 0 & 1.281 \\
\hline
\end{tabular}

Note: meq: Milliequivalent, K: Potassium, Na: Sodium, Ca: Calcium, Mg: Magnesium, $\mathrm{Cl}$ : Chloride, $\mathrm{CO}_{3}$ : Carbonate, $\mathrm{HCO}_{3}$ : Bicarbonate, $\mathrm{EC}$ : Electrical conductivity $\left(\mathrm{ds} . \mathrm{m}^{-1}\right)$, O.M: Organic matter $(\%)$. 
Table 2. Mechanical analysis of soil sample for wheat plant

\begin{tabular}{|c|c|c|c|c|}
\hline \multicolumn{4}{|c|}{ The relative distribution of soil granules (\%) } & Texture \\
\hline Coarse sand & Fine sand & Silt & Clay & \\
\hline 45.95 & 26.33 & 10.17 & 17.52 & Sandy loam \\
\hline
\end{tabular}

\section{Biochemical analyses}

Determination of total chlorophyll content: Total chlorophyll was measured using chlorophyll meter SPAD-502 (Konica-Minolta, Osaka, Japan) according to manufacturer's instructions.

Determination of starch, fiber, ash and fat contents: Starch, fiber, ash and fat contents were measured using NIRS ${ }^{\text {TM }}$ DA1650 Analyser (Foss Allé 1, Hilleroed, Denmark) according to manufacturer's instructions.

\section{Assay of enzyme activities}

\section{Enzymes extraction:}

Extraction of catalase and peroxidase enzymes: Extraction of catalase (CAT) and peroxidase (POX) enzymes were performed according to Kongngern et al., (2012). Leaf samples (0.5 g) were homogenized in ice-cold 0.1 M phosphate buffer ( $\mathrm{pH}$ 7.5) containing 0.5 mM EDTA, 1mM polyethyleneglycol, 1mM phenylmethelsulfonyl fluoride and $0.01 \%(\mathrm{v} / \mathrm{v})$ triton $\mathrm{x}-100$ with pre-chilled pestle and mortar. Centrifuge tubes were used for each homogenate and were centrifuged at $4^{\circ} \mathrm{C}$ for $15 \mathrm{~min}$ at $15,000 \times \mathrm{g}$. The supernatants were used for enzyme activity assay.

Extraction of ascorbate peroxidase enzyme: Extraction of ascorbate peroxidase enzyme was performed according to Kong-ngern et al., (2012). Leaf samples $(0.5 \mathrm{~g})$ were homogenized in ice-cold $0.1 \mathrm{M}$ phosphate buffer $(\mathrm{pH} \quad 7.5)$ containing $0.5 \mathrm{mM}$ EDTA, $2 \mathrm{mM}$ ascorbate, $1 \mathrm{mM}$ 
polyethyleneglycol, $1 \mathrm{mM}$ phenylmethelsulfonyl fluoride, $5 \%$ polyvinylpyrrolidin and $0.01 \%(\mathrm{v} / \mathrm{v})$ triton X-100 with pre-chilled pestle and mortar. The following stages were similar to the extraction of other enzymes Activity of catalase enzyme: Catalase activity was measured according to Aebi (1984). About $3 \mathrm{ml}$ reaction mixture containing $1.5 \mathrm{ml}$ of $100 \mathrm{mM}$ potassium phosphate buffer ( $\mathrm{pH} 7$ ), $0.5 \mathrm{ml}$ of $75 \mathrm{mM} \mathrm{H}_{2} \mathrm{O}_{2}, 0.05 \mathrm{ml}$ enzyme extraction and distilled water to make up the volume to $3 \mathrm{ml}$. Reaction started by adding $\mathrm{H}_{2} \mathrm{O}_{2}$ and decrease in absorbance recorded at $240 \mathrm{~nm}(\varepsilon=36$ $\mathrm{mM}^{-1} \cdot \mathrm{cm}^{-1}$ ) for $1 \mathrm{~min}$. Enzyme activity was computed by calculating the amount of $\mathrm{H}_{2} \mathrm{O}_{2}$ decomposed.

Activity of ascorbate peroxidase enzyme: Activity of ascorbate peroxidase was measured according to Yoshimura et al., (2000) by monitoring the rate of ascorbate oxidation at $290 \mathrm{~nm}\left(\varepsilon=2.8 \mathrm{mM}^{-1} \mathrm{~cm}^{-1}\right)$. The reaction mixture contained $25 \mathrm{mM}$ phosphate buffer (pH 7), $0.1 \mathrm{mM}$ EDTA, $1 \mathrm{mM} \mathrm{H}_{2} \mathrm{O}_{2}, 0.25$ $\mathrm{mM}$ ascorbic acid and $0.05 \mathrm{ml}$ enzyme extraction. Enzyme activity was computed by calculating the amount of $\mathrm{H}_{2} \mathrm{O}_{2}$ decomposed.

Activity of peroxidase enzyme:Peroxidase activity was measured by following the change of absorbtion at $470 \mathrm{~nm}$ due to guaiacol oxidation. Peroxidase activity was measured according to Polle et al., (1994), reaction mixture contained $100 \mathrm{mM}$ potassium phosphate buffer ( $\mathrm{pH}$ 7), $10 \mathrm{mM} \mathrm{H}_{2} \mathrm{O}_{2}$, $20 \mathrm{mM}$ guaiacol, $0.05 \mathrm{ml}$ enzyme extraction and distilled water to make up the volume to $3 \mathrm{ml}$. Reaction started by adding $\mathrm{H}_{2} \mathrm{O}_{2}$ and decrease in absorbance recorded at $470 \mathrm{~nm}\left(\varepsilon=26.6 \mathrm{mM}^{-1} \cdot \mathrm{cm}^{-1}\right)$ for $1 \mathrm{~min}$. Enzyme activity was computed by calculating the amount of $\mathrm{H}_{2} \mathrm{O}_{2}$ decomposed. 
Statistical analysis: The data for all parameters were statistically analyzed using MSTAT software. Each treatment was analyzed in three replicates. Analysis of variance (ANOVA) showed significant treatment effects, Duncan's Multiple Range Test was applied to compare the means at $\mathrm{P}<0.05$.

\section{RESULTS AND DISCUSSION}

The experiment was conducted under greenhouse conditions with wheat (Triticum aestivum L.) cultivar sakha 93. Three replicates, five grains per replicate were sown directly in plastic pots. This experiment was carried out to study the effect of adding different compounds on growth, yield and some physiological parameters of wheat plants under different salinity levels. Treatments were (i) control: plants receiving tap water, (ii) salinity treatment: plants receiving different concentrations from sea salt, (iii) salinity plus supplementary: plants receiving different concentrations from sea salt plus application of proline, ascorbic acid, arginine, glutathione and glutamine. The results obtained from this experiment revealed that growth parameters such as shoot length, root weight and grain weight, in addition to biochemical compounds such as chlorophyll, carbohydrate, starch, protein, fiber, ash and fat content were affected by both salt and treatments. These parameters were decreased in response to salinity stress compared to untreated plants. The decrement in the growth parameters and biochemical compounds were found to be increased with increasing salt concentrations, particularly at $6000 \mathrm{mg} / \mathrm{l}$, $8000 \mathrm{mg} / \mathrm{l}$ and $10000 \mathrm{mg} / \mathrm{l}$ respectively. Five compounds represented in proline, ascorbic acid, arginine, glutathione and glutamine were used as exogenous application under different salinity level. Growth parameters and 
biochemical compounds were improved when adding these compounds to plants compared with control plants. The data were recorded after 120 days of growing and were subjected to analysis of variance (ANOVA) and treatment means comparison using MSTAT statistical analysis program. Significance between treatments was compared at the 0.05 probability level.

Shoot length: Analysis of variance (ANOVA) of data presented in Table 3 shows that salt stress significantly decreases the shoot length compared with untreated plants, the decrement was found to be increased with increasing salt concentrations, particularly at $6000 \mathrm{mg} / \mathrm{l}, 8000 \mathrm{mg} / \mathrm{l}$ and $10000 \mathrm{mg} / \mathrm{l}$ respectively. Otherwise, addition of proline, ascorbic acid, arginine, glutathione and glutamine showed significant increases in shoot length compared with control plants under different salinity levels (Table 4). The increase of shoot length over control was 8.7, 10.9, 21.7, 23.9 and 19.6\% when treated with proline, ascorbic acid, arginine, glutathione and glutamine respectively at $6000 \mathrm{mg} / \mathrm{l}$, while the increase over control was 4.3, 8.6, 15.2, 19.6 and $13 \%$ at $8000 \mathrm{mg} / \mathrm{l}$ respectively. The increase of shoot length over control was $6.8,9.1,13.6,16$ and $11.4 \%$ at $10000 \mathrm{mg} / \mathrm{l}$. Nevertheless the highest value of shoot length at $10000 \mathrm{mg} / \mathrm{l}$ was recorded when treated with glutathione compared with control plants followed by arginine, glutamine, ascorbic acid and proline respectively. These results are in agreement with those obtained by Hassanein et al., (2009) who found that shoot height of Zea mays plants were significantly decreased with increasing the salinity level. Similar finding has been reported by Karima, (2005) who performed the experiment on sunflower plant under salt stress and the effect of application 
of ascorbic acid that led to significant increase in shoot length. Other authers studied the effect of exogenous application of ascorbic acid on other plant species as Hassanein et al., (2009) on Zea mays, who found that shoot height is increasing by the addition of ascorbic acid. Moreover, AL-Mayahi (2016) found a progressive increase in plant height, by increasing ascorbic acid level in date palm plant (Phoenix dactylifera L.). Also Athar et al., (2008) suggested that ascorbic acid could accelerate cell division and improve the growth.

Table 3. Effect of salt stress on wheat growth parameters.

\begin{tabular}{|c|c|c|c||}
\hline $\begin{array}{c}\text { Parameter } \\
\text { Treatmant }\end{array}$ & $\begin{array}{c}\text { Root dry weight } \\
\text { (gm/plant) }\end{array}$ & $\begin{array}{c}\text { Shoot length } \\
(\mathbf{c m})\end{array}$ & $\begin{array}{c}\text { Thousand grain } \\
\text { weight }(\mathbf{g m})\end{array}$ \\
\hline \hline control $^{*}$ & $0.45 \mathrm{a}$ & $49.0 \mathrm{a}$ & $40 \mathrm{a}$ \\
\hline sea salt $6000 \mathrm{mg} / \mathrm{l}$ & $0.43 \mathrm{ab}$ & $46.0 \mathrm{~b}$ & $35 \mathrm{~b}$ \\
\hline sea salt $8000 \mathrm{mg} / \mathrm{l}$ & $0.41 \mathrm{ab}$ & $45.5 \mathrm{c}$ & $32 \mathrm{c}$ \\
\hline sea salt $10000 \mathrm{mg} / \mathrm{l}$ & $0.37 \mathrm{~b}$ & $44.0 \mathrm{~d}$ & $29 \mathrm{~d}$ \\
\hline
\end{tabular}

Note: Values have the same letter in the same column are not significantly different at $\mathrm{LSD} \leq 0.05$ level according to Duncan's Multiple Range Test (DMRT). *Wheat plants irrigated with tap water. 
Table 4. Effect of proline, ascorbic acid, arginine, glutathione and glutamine on shoot length of wheat plants under different salinity levels.

\begin{tabular}{|c|c|c|c|c|}
\hline \multicolumn{5}{|c|}{ Shoot length $(\mathrm{cm})$} \\
\hline Treatments & $6000 \mathrm{mg} / \mathrm{l}$ & $8000 \mathrm{mg} / \mathrm{l}$ & $10000 \mathrm{mg} / \mathrm{l}$ & Mean \\
\hline Control* & $46.00 \mathrm{i}$ & $46.00 \mathrm{i}$ & $44.00 \mathrm{j}$ & $45.33 \mathrm{~d}$ \\
\hline Proline & 50.00 ef & $48.00 \mathrm{gh}$ & $47.00 \mathrm{hi}$ & $48.33 \mathrm{c}$ \\
\hline Ascorbic acid & $51.00 \mathrm{de}$ & 50.00 ef & $48.00 \mathrm{gh}$ & $49.67 \mathrm{c}$ \\
\hline Arginine & $56.00 \mathrm{ab}$ & $53.00 \mathrm{c}$ & 50.00 ef & $53.00 \mathrm{ab}$ \\
\hline Glutathione & $57.00 \mathrm{a}$ & $55.00 \mathrm{~b}$ & $51.00 \mathrm{DE}$ & $54.33 \mathrm{a}$ \\
\hline Glutamine & $55.00 \mathrm{~b}$ & $52.00 \mathrm{~cd}$ & $49.00 \mathrm{fg}$ & $52.00 \mathrm{~b}$ \\
\hline Mean & $52.50 \mathrm{a}$ & $50.67 \mathrm{~b}$ & $48.17 \mathrm{c}$ & \\
\hline
\end{tabular}

Note: Values have the same letter in the same column are not significantly different at $\mathrm{LSD} \leq 0.05$ level according to Duncan's Multiple Range Test (DMRT). *Wheat plants treated with sea salt only.

Grain weight: ANOVA Table 3 shows that salt stress significantly decreases the weight of thousand grains compared with untreated plants, the decrement was found to be increased with increasing salt concentrations, particularly at $6000 \mathrm{mg} / \mathrm{l}, 8000 \mathrm{mg} / \mathrm{l}$ and $10000 \mathrm{mg} / \mathrm{l}$ respectively. However, exogenous application of proline, ascorbic acid, arginine, glutathione and glutamine showed improvement and significant increases in this parameter compared with control plants under different salinity levels (Table 5). Grain weight increase over control was $20,21.4,25.7,28.5$ and $22.9 \%$ when treated with proline, ascorbic acid, arginine, glutathione and glutamine respectively at $6000 \mathrm{mg} / \mathrm{l}$, while the increase of grain weight over control was 28.1, 28.1, $31.3,37.5$ and $31.3 \%$ respectively at $8000 \mathrm{mg} / \mathrm{l}$. The increase over control at $10000 \mathrm{mg} / \mathrm{l}$ was 34.5, 38, 39.7, 41.4 and 38\% respectively. Moreover the highest value of grain weight was recorded when treated with glutathione compared with control plants followed by arginine, ascorbic acid and 
glutamine which have the same values while the lowest values were recorded with proline when using high salinity level $(10000 \mathrm{mg} / \mathrm{l})$. These findings are in accordance of the results obtained previously by Zadeh and Naeini, (2007); Hussein et al., (2008); Hussein et al., (2011); Hozayn et al., (2013), in which they reported that grain weight was reduced by increasing rate of salts application into soil. On the other hand, when treating with ascorbic acid under salinity conditions a significant increase in grain weight of grapevine and Soybean was evedent (Fayed, 2010; Sheteaw, 2007). Moreover, ElBassiouny and Bekheta (2001) reported that treatment application of wheat with arginine increased significantly grain weight as compared with control plants under salinity condition. They also mentioned that arginine is intimately involved in salt treated wheat plant thereby regulating growth, and grain yield.

Table 5. Effect of proline, ascorbic acid, arginine, glutathione and glutamine on grain weight of wheat plants under different salinity levels.

\begin{tabular}{|c|c|c|c|c|}
\hline \multicolumn{7}{|c|}{ Thousand grain weight (gm) } \\
\hline Treatments & $\mathbf{6 0 0 0} \mathbf{~ m g / l}$ & $\mathbf{8 0 0 0} \mathbf{~ m g} / \mathbf{l}$ & $\mathbf{1 0 0 0 0} \mathbf{~ m g} / \mathbf{l}$ & Mean \\
\hline \hline Control* & $35.00 \mathrm{~h}$ & $32.00 \mathrm{i}$ & $29.00 \mathrm{j}$ & $32.00 \mathrm{c}$ \\
\hline Proline & $42.00 \mathrm{cde}$ & $41.00 \mathrm{def}$ & $39.00 \mathrm{~g}$ & $40.67 \mathrm{~b}$ \\
\hline Ascorbic acid & $42.50 \mathrm{bcd}$ & $41.00 \mathrm{def}$ & $40.00 \mathrm{fg}$ & $41.17 \mathrm{~b}$ \\
\hline Arginine & $44.00 \mathrm{ab}$ & $42.00 \mathrm{cde}$ & $40.50 \mathrm{efg}$ & $42.17 \mathrm{ab}$ \\
\hline Glutathione & $45.00 \mathrm{a}$ & $44.00 \mathrm{ab}$ & $41.00 \mathrm{def}$ & $43.33 \mathrm{a}$ \\
\hline Glutamine & $43.00 \mathrm{bc}$ & $42.00 \mathrm{cde}$ & $40.00 \mathrm{fg}$ & $41.67 \mathrm{ab}$ \\
\hline Mean & $41.92 \mathrm{a}$ & $40.33 \mathrm{a}$ & $38.25 \mathrm{~b}$ & \\
\hline
\end{tabular}

Note: Values have the same letter in the same column are not significantly different at LSD $\leq 0.05$ level according to Duncan's Multiple Range Test (DMRT). *Wheat plants treated with sea salt only. 
Root weight: Data presented in Table 3 shows that salt stress has a negative effect on root dry weight and significantly decreased it compared with untreated plants. Otherwise, the application of proline, ascorbic acid, arginine, glutathione and glutamine showed significant increases in root dry weight compared with control plants under different salinity levels (Table 6). However the increase of root weight over control was 16.3, 37.2, 34.9, 32.6 and $30.2 \%$ when treated with proline, ascorbic acid, arginine, glutathione and glutamine respectively at $6000 \mathrm{mg} / \mathrm{l}$, while root dry weight increases over control were $14.6,24.4,22,26.8$ and $19.5 \%$ respectively at $8000 \mathrm{mg} / \mathrm{l}$. The increase over control was 8.1,29.7, 24.3, 27 and $21.6 \%$ respectively at 10000 $\mathrm{mg} / \mathrm{l}$. Nevertheless the highest value of root weight at $10000 \mathrm{mg} / \mathrm{l}$ was recorded when treated with ascorbic acid compared with control plants followed by arginine, glutathione, glutamine and proline respectively. These results were similar to that obtained by Khan et al., (2003) who reported that the effect of ascorbic acid on growth improvement comes from the fact that they act as an antioxidant under salinity. Our results are consistent with previous reports that different antioxidants such as ascorbic acid mitigated salinity effects and thus enhanced salt tolerance on various crop plants. These authors proposed that antioxidants ameliorate the damaging effect of salinity through interaction of antioxidant response and protection of membranes (Ekmekçi and Karaman, 2012). Furthermore, there are some reports which provide evidence that ascorbic acid accelerates cell division and cell enlargement as observed in different plants such as Pisum (Cabo et al., 1996), and Lupinus albus (Citterio et al., 1994). These findings suggest that growth 
promoting effect of ascorbic acid under saline conditions may have been due to enhanced antioxidant capacity and increase in cell division and cell enlargement. Moreover, Couée et al., (2004) indicated that the stimulation of polyamines to root growth and development may be related to the high flexibility of polyamine metabolism and the metabolic link between polyamine and ethylene synthesis which strongly suggest that, polyamines may play a role in environmentally induced plasticity of root development. The increase in fresh and dry root weight of plants treated with arginine is a reflection to the increase in growth rate cell division and/or cell enlargement and differentiation (Lixiong et al., 2002). Also, these effects of arginine may be due to that polyamine have been implicated in a wide range of biological processes including growth development and abiotic stress responses and cell division and differentiation (Nasibi et al., 2014).

Table 6. Effect of proline, ascorbic acid, arginine, glutathione and glutamine on root weight of wheat plants under different salinity levels.

\begin{tabular}{||c|c|c|c|c|}
\hline \multicolumn{7}{|c|}{ Root dry weight $\mathbf{( g m / p l a n t )}$} \\
\hline Treatments & $\mathbf{6 0 0 0} \mathbf{~ m g / l}$ & $\mathbf{8 0 0 0} \mathbf{~ m g / l}$ & $\mathbf{1 0 0 0 0} \mathbf{~ m g} / \mathbf{l}$ & Mean \\
\hline \hline Control* & $0.43 \mathrm{ab}$ & $0.41 \mathrm{ab}$ & $0.37 \mathrm{~b}$ & $0.4033 \mathrm{a}$ \\
\hline Proline & $0.50 \mathrm{ab}$ & $0.46 \mathrm{ab}$ & $0.40 \mathrm{ab}$ & $0.4733 \mathrm{a}$ \\
\hline Ascorbic acid & $0.59 \mathrm{a}$ & $0.51 \mathrm{ab}$ & $0.48 \mathrm{ab}$ & $0.5200 \mathrm{a}$ \\
\hline Arginine & $0.58 \mathrm{a}$ & $0.50 \mathrm{ab}$ & $0.46 \mathrm{ab}$ & $0.5100 \mathrm{a}$ \\
\hline Glutathione & $0.57 \mathrm{a}$ & $0.59 \mathrm{ab}$ & $0.45 \mathrm{ab}$ & $0.5100 \mathrm{a}$ \\
\hline Glutamine & $0.56 \mathrm{a}$ & $0.47 \mathrm{ab}$ & $0.45 \mathrm{ab}$ & $0.4567 \mathrm{a}$ \\
\hline Mean & $0.5267 \mathrm{a}$ & $0.4750 \mathrm{a}$ & $0.4350 \mathrm{a}$ & \\
\hline
\end{tabular}

Note: Values have the same letter in the same column are not significantly different at LSD $\leq 0.05$ level according to Duncan's Multiple Range Test (DMRT). *Wheat plants treated with sea salt only. 
Total chlorophyll content: Analysis of variance (ANOVA) of data presented in Table 7 shows that treatments significantly affected total chlorophyll content in leaves. This photosynthetic pigment tends to decrease with increasing salinity level. Treating salt-stressed wheat plant with proline, ascorbic acid, arginine, glutathione and glutamine significantly increased the production of photosynthetic pigment (chlorophyll) compared with control plants under different salinity levels (Table 8). However, increase of total chlorophyll over control was 1.7, 7.8, 9.5, 13.2 and $21.4 \%$ when treated with proline, ascorbic acid, arginine, glutathione and glutamine respectively at $6000 \mathrm{mg} / \mathrm{l}$, while the increase over control was $2.5,5,6.2,6.5$ and $7.1 \%$ respectively at $8000 \mathrm{mg} / \mathrm{l}$. The increase of total chlorophyll over control at $10000 \mathrm{mg} / \mathrm{l}$ was $2.9,4.5,6,6.2$, and $7.6 \%$ respectively. Nevertheless the highest value of total chlorophyll was recorded when treated with glutamine compared with control plants followed by glutathione, arginine, ascorbic acid and proline respectively when using high salinity level $(10000 \mathrm{mg} / \mathrm{l})$. These results are in agreement with those obtained by Ghassemi-Golezaniet et al., (2012), Hellal et al., (2012) and Bahari et al., (2013), they stated that the reductions are due to the inhibitory effects of salinity on many metabolic processes including, activity of mitochondria and chloroplasts. Also, ElBagoury et al., (1999) suggested that, the biosynthesis of chlorophylls in generally might be inhibited by the depressive effect of stress conditions on the absorption of some ions involved in the chloroplast formation. Moreover, Fayed, (2010), Sheteaw, (2007) and Maksoud et al., (2009) reported that the treatment with ascorbic acid mitigated salinity induced effect on chlorophyll 
reductions. The beneficial effect of ascorbic acid as antioxidant on photosynthetic pigments may be due to its role in decreasing the rate of photochemical reduction, chloroplast structure, photosynthetic electron transfer as well as photosynthesis (Kumar et al., 1988). Ali et al., (2007) and Sharkey et al., (2007) had treated wheat plant with proline under salinity stress. They found a considerable enhancement of total chlorophyll content. They suggested that the increase in chlorophyll content due to exogenous proline application primarily increased the rate of $\mathrm{CO}_{2}$ diffusion and favored higher photosynthetic rate. Similar promoting effects of arginine on photosynthetic pigments had been observed by Nassar et al. (2003) and ElBassiouny et al., (2008). A possible explanation for the promoting effect of arginine on photosynthetic pigment of wheat plant in their work is that arginine might retard chlorophyll destruction and or increase their biosynthesis or stabilize the thylakoid membrane (Gonzalez et al., 1997). They also demonstrated that arginine may retard senescence via altering the stability and permeability of such membranes and protecting membranes and prevent chloroplast from senescing and therefore retarding chlorophyll loss. The role of arginine in chlorophyll synthesis is supported by HuiGuo et al., (2006) who found that exogenous application of arginine protects photosystem II (PSII) against water stress at both transcriptional and translational levels. Also, it allows PSII to retain a higher activity level during stress in wheat seedlings resulting in the increase in chlorophyll contents. Moreover, these increases could be attributed to the role of magnesium as a structural component of chlorophyll and reinforced the role of arginine in chlorophyll biosynthesis (Krishnamurthy, 1991). 
Table 7. Effect of salt stress on some biochemical composition of wheat plants.

\begin{tabular}{|r|c|c|c|c|c|}
\hline \multicolumn{1}{|c|}{ Parameter } & $\begin{array}{c}\text { Total } \\
\text { chlorophyll }^{\text {Treatment }}\end{array}$ & $\begin{array}{c}\text { Starch } \\
(\boldsymbol{\%})\end{array}$ & $\begin{array}{c}\text { Fiber } \\
(\boldsymbol{\%})\end{array}$ & $\begin{array}{c}\text { Ash } \\
(\boldsymbol{\%})\end{array}$ & Fat (\%) \\
\hline \hline control* & $49.1 \mathrm{a}$ & $69.04 \mathrm{a}$ & $2 \mathrm{a}$ & $1.8 \mathrm{a}$ & 1.8 \\
\hline sea salt $6000 \mathrm{mg} / \mathrm{l}$ & $46.3 \mathrm{~b}$ & $64.93 \mathrm{~b}$ & $1.5 \mathrm{~b}$ & $1.6 \mathrm{~b}$ & $1.7 \mathrm{~b}$ \\
\hline sea salt $8000 \mathrm{mg} / \mathrm{l}$ & $43.5 \mathrm{c}$ & $62 \mathrm{c}$ & $1.3 \mathrm{c}$ & $1.5 \mathrm{c}$ & $1.55 \mathrm{c}$ \\
\hline sea salt $10000 \mathrm{mg} / \mathrm{l}$ & $42.3 \mathrm{~d}$ & $59 \mathrm{~d}$ & $1 \mathrm{~d}$ & $1.45 \mathrm{~d}$ & $1.35 \mathrm{~d}$ \\
\hline
\end{tabular}

Note: Effect of different salinity level on total chlorophyll in leaves and different contents of grains: total carbohydrate, starch, total protein, fiber, ash and fat. Values have the same letter in the same column are not significantly different at LSD $\leq 0.05$ level according to Duncan's Multiple Range Test (DMRT). *Wheat plants irrigated with tap water.

Table 8. Effect of proline, ascorbic acid, arginine, glutathione and glutamine on total chlorophyll of wheat plants under different salinity levels.

\begin{tabular}{|l|l|l|l|l|}
\hline \multicolumn{7}{|c|}{ Total chlorophyll $\left(\boldsymbol{\mu g} \mathbf{~ c m}^{-2}\right)$} \\
\hline \multicolumn{1}{|c|}{ Treatments } & $\mathbf{6 0 0 0} \mathbf{~ m g} / \mathbf{~}$ & $\mathbf{8 0 0 0} \mathbf{~ m g} / \mathbf{l}$ & $\mathbf{1 0 0 0 0} \mathbf{~ m g} / \mathbf{l}$ & Mean \\
\hline \hline Control* & $46.3 \mathrm{hi}$ & $43.5 \mathrm{j}$ & $42.3 \mathrm{j}$ & $44.03 \mathrm{~d}$ \\
\hline Proline & $47.1 \mathrm{fgh}$ & $46.0 \mathrm{hi}$ & $45.2 \mathrm{i}$ & $46.10 \mathrm{c}$ \\
\hline Ascorbic acid & $48.9 \mathrm{def}$ & $48.5 \mathrm{efg}$ & $46.8 \mathrm{ghi}$ & $48.07 \mathrm{~b}$ \\
\hline Arginine & $51.7 \mathrm{bc}$ & $49.7 \mathrm{de}$ & $48.3 \mathrm{efg}$ & $50.07 \mathrm{a}$ \\
\hline Glutathione & $52.4 \mathrm{~b}$ & $50.0 \mathrm{cde}$ & $48.5 \mathrm{efg}$ & $50.97 \mathrm{a}$ \\
\hline Glutamine & $56.2 \mathrm{a}$ & $50.6 \mathrm{~cd}$ & $49.9 \mathrm{de}$ & $51.40 \mathrm{a}$ \\
\hline \multicolumn{1}{|c|}{ Mean } & $50.43 \mathrm{a}$ & $48.05 \mathrm{~b}$ & $46.83 \mathrm{~b}$ & \\
\hline
\end{tabular}

Note: Values have the same letter in the same column are not significantly different at LSD $\leq 0.05$ level according to Duncan's Multiple Range Test (DMRT). *Wheat plants treated with sea salt only.

Starch content: Analysis of variance (ANOVA) of data presented in Table 7 shows that salt stress significant decreases the starch content in grains compared with untreated plants. The results recorded in the same table indicated that, starch content was significantly decreased with increasing salt 
concentrations, particularly at $6000 \mathrm{mg} / \mathrm{l}, 8000 \mathrm{mg} / \mathrm{l}$ and $10000 \mathrm{mg} / \mathrm{l}$ respectively. The results also showed that, application of proline, ascorbic acid, arginine, glutathione and glutamine increased the starch content compared with control plants under different salinity levels (Table 9). However, increase of starch content over control was 7.5, 6.3, 6.2, 7.4 and $4.7 \%$ respectively at $6000 \mathrm{mg} / \mathrm{l}$, while increase was recorded when using the same treatments by $12,10.8,12.6,12.1$ and $10.5 \%$ respectively at $8000 \mathrm{mg} / \mathrm{l}$. Whereas at $10000 \mathrm{mg} / \mathrm{l}$ the increase over control was $14.1,12.4,12.7,12.9$ and $10.2 \%$ respectively for the same treatments. Moreover the highest value of starch content was recorded when treated with proline compared with control plants followed by glutathione, arginine ascorbic acid and glutamine respectively when using the highest concentration of sea salt $(10000 \mathrm{mg} / \mathrm{l})$.

Table 9. Effect of proline, ascorbic acid, arginine, glutathione and glutamine on starch content of wheat plants under different salinity levels.

\begin{tabular}{|l|l|l|l|l||}
\hline \multicolumn{7}{|c|}{ Starch (\%) } \\
\hline \multicolumn{1}{|c|}{ Treatments } & $\mathbf{6 0 0 0} \mathbf{~ m g / l}$ & $\mathbf{8 0 0 0} \mathbf{~ m g / l}$ & $\mathbf{1 0 0 0 0} \mathbf{~ m g / l}$ & Mean \\
\hline \hline Control* & $64.93 \mathrm{~d}$ & $62.00 \mathrm{e}$ & $59.00 \mathrm{f}$ & $61.98 \mathrm{~b}$ \\
\hline Proline & $69.82 \mathrm{a}$ & $69.41 \mathrm{a}$ & $67.30 \mathrm{bc}$ & $68.84 \mathrm{a}$ \\
\hline Ascorbic acid & $68.99 \mathrm{ab}$ & $68.72 \mathrm{ab}$ & $66.32 \mathrm{~cd}$ & $68.01 \mathrm{a}$ \\
\hline Arginine & $68.98 \mathrm{ab}$ & $69.80 \mathrm{a}$ & $66.50 \mathrm{~cd}$ & $68.43 \mathrm{a}$ \\
\hline Glutathione & $69.78 \mathrm{a}$ & $69.53 \mathrm{a}$ & $66.60 \mathrm{~cd}$ & $68.64 \mathrm{a}$ \\
\hline Glutamine & $68.00 \mathrm{abc}$ & $68.50 \mathrm{ab}$ & $65.00 \mathrm{~d}$ & $67.17 \mathrm{a}$ \\
\hline \multicolumn{1}{|c|}{ Mean } & $68.42 \mathrm{a}$ & $67.99 \mathrm{a}$ & $67.99 \mathrm{a}$ & \\
\hline
\end{tabular}

Note: Values have the same letter in the same column are not significantly different at LSD $\leq 0.05$ level according to Duncan's Multiple Range Test (DMRT). *Wheat plants treated with sea salt only. 
Fiber content: ANOVA Table 7 shows that salt stress significantly decreases the fiber content in wheat grains compared with untreated plants. However, fiber content decreased significantly and gradually with increasing salt concentrations, particularly at $6000 \mathrm{mg} / \mathrm{l}, 8000 \mathrm{mg} / \mathrm{l}$ and $10000 \mathrm{mg} / \mathrm{l}$ respectively. On the other hand, addition of proline, ascorbic acid, arginine, glutathione and glutamine increased significantly fiber content compared with control plants under different salinity levels (Table 10). The increase of fiber content over control was 40,46.7, 33.3, 66.6 and 53.3\% respectively at 6000 $\mathrm{mg} / \mathrm{l}$, while increase was recorded when using the same treatments by 69.2, $84.6,61.5,92.3$ and $53.8 \%$ respectively at $8000 \mathrm{mg} / \mathrm{l}$. Whereas at $10000 \mathrm{mg} / \mathrm{l}$ the increases over control were 90, 80, 91, 100 and 70\% respectively. Moreover the highest value of fiber content was recorded when treated with glutathione compared with control plants followed by arginine, proline, ascorbic acid and glutamine respectively when using the highest concentration of sea salt $(10000 \mathrm{mg} / \mathrm{l})$. These results were similar to that obtained by Maqsood et al., (2008) who reported that a decrease in fiber content accumulation in maize grain is associated with salt stress. 
Table 10. Effect of proline, ascorbic acid, arginine, glutathione and glutamine on fiber content of wheat plants under different salinity levels.

\begin{tabular}{|l|l|l|l|l||}
\hline \multicolumn{7}{|c|}{ Fiber content (\%) } \\
\hline \multicolumn{1}{|c|}{ Treatments } & $\mathbf{6 0 0 0} \mathbf{~ m g / l}$ & $\mathbf{8 0 0 0} \mathbf{~ m g} / \mathbf{l}$ & $\mathbf{1 0 0 0 0} \mathbf{~ m g} / \mathbf{l}$ & Mean \\
\hline Control* & $1.5 \mathrm{i}$ & $1.3 \mathrm{j}$ & $1.0 \mathrm{k}$ & $1.267 \mathrm{c}$ \\
\hline Proline & $2.1 \mathrm{de}$ & $2.2 \mathrm{~cd}$ & $1.9 \mathrm{fg}$ & $2.067 \mathrm{~b}$ \\
\hline Ascorbic acid & $2.2 \mathrm{~cd}$ & $2.4 \mathrm{ab}$ & $1.8 \mathrm{gh}$ & $2.133 \mathrm{ab}$ \\
\hline Arginine & $2.0 \mathrm{ef}$ & $2.1 \mathrm{de}$ & $1.9 \mathrm{fg}$ & $2.000 \mathrm{~b}$ \\
\hline Glutathione & $2.5 \mathrm{a}$ & $2.5 \mathrm{a}$ & $2.9 \mathrm{ef}$ & $2.267 \mathrm{a}$ \\
\hline Glutamine & $2.3 \mathrm{bc}$ & $2.0 \mathrm{ef}$ & $1.7 \mathrm{~h}$ & $2.067 \mathrm{~b}$ \\
\hline \multicolumn{1}{|c|}{ Mean } & $2.100 \mathrm{a}$ & $2.083 \mathrm{a}$ & $1.717 \mathrm{~b}$ & \\
\hline
\end{tabular}

Note: Values have the same letter in the same column are not significantly different at $\mathrm{LSD} \leq 0.05$ level according to Duncan's Multiple Range Test (DMRT). *Wheat plants treated with sea salt only.

Ash content: Analysis of variance (ANOVA) of data presented in Table 7 indicated that salt stress significant decreases the ash content in wheat grains compared with untreated plants. The data recorded in the same table indicated that the ash content was significantly decreased with increasing salinity level. Moreover the obtained data in table (11) clearly demonstrated that the application of proline, ascorbic acid, arginine, glutathione and glutamine showed significant increases in ash content compared with control plants under different salinity levels. Ash content increase over control was 15.6, 16.9, 17.5, 18.1 and 14.4\% when treated with proline, ascorbic acid, arginine, glutathione and glutamine respectively at $6000 \mathrm{mg} / \mathrm{l}$, while the increases over control were $34,35,36,37$ and $31 \%$ respectively at $8000 \mathrm{mg} / \mathrm{l}$. However the increase in this parameter was $24.8,26.2,26.9,27.6$ and $24.1 \%$ respectively at $10000 \mathrm{mg} / \mathrm{l}$ for the same treatments. Moreover the highest value of ash content was recorded when treated with glutathione compared with control 
plants followed by arginine, proline, ascorbic acid and glutamine respectively under high salinity condition $(10000 \mathrm{mg} / \mathrm{l})$.

Table 11. Effect of proline, ascorbic acid, arginine, glutathione and glutamine on ash content of wheat plants under different salinity levels.

\begin{tabular}{|l|c|c|c|c||}
\hline \multicolumn{7}{|c||}{ Ash content (\%) } \\
\hline \multicolumn{1}{|c|}{ Treatments } & $\mathbf{6 0 0 0} \mathbf{~ m g / l}$ & $\mathbf{8 0 0 0} \mathbf{~ m g / l}$ & $\mathbf{1 0 0 0 0} \mathbf{~ m g / l}$ & Mean \\
\hline \hline Control* & $1.60 \mathrm{~b}$ & $1.50 \mathrm{~b}$ & $1.45 \mathrm{~b}$ & $1.517 \mathrm{~b}$ \\
\hline Proline & $1.85 \mathrm{a}$ & $1.84 \mathrm{a}$ & $1.81 \mathrm{a}$ & $1.833 \mathrm{a}$ \\
\hline Ascorbic acid & $1.87 \mathrm{a}$ & $1.85 \mathrm{a}$ & $1.83 \mathrm{a}$ & $1.850 \mathrm{a}$ \\
\hline Arginine & $1.88 \mathrm{a}$ & $1.86 \mathrm{a}$ & $1.84 \mathrm{a}$ & $1.863 \mathrm{a}$ \\
\hline Glutathione & $1.89 \mathrm{a}$ & $1.87 \mathrm{a}$ & $1.85 \mathrm{a}$ & $1.867 \mathrm{a}$ \\
\hline Glutamine & $1.83 \mathrm{a}$ & $1.81 \mathrm{a}$ & $1.80 \mathrm{a}$ & $1.813 \mathrm{a}$ \\
\hline Mean & $1.820 \mathrm{a}$ & $1.788 \mathrm{a}$ & $1.763 \mathrm{a}$ & \\
\hline
\end{tabular}

Note: Values have the same letter in the same column are not significantly different at LSD $\leq 0.05$ level according to Duncan's Multiple Range Test (DMRT). *Wheat plants treated with sea salt only.

Fat content: As show in ANOVA Table 7, salt stress significantly decreases the fat content in wheat grains compared with untreated plants. The results recorded in the same table indicated that, fat content was significantly decreased with increasing salt concentrations. The results also revealed that, application of proline, ascorbic acid, arginine, glutathione and glutamine showed significant increases in fat content compared with control plants under different salinity levels (Table 12). However, fat content increase over control was 14.7, 11.8, 10.6, 12.9 and 9.4\% when treated with proline, ascorbic acid, arginine, glutathione and glutamine respectively at $6000 \mathrm{mg} / \mathrm{l}$, while the increases over control were 18.1, 13.5, 17.4, 16.8 and $14.8 \%$ respectively at $8000 \mathrm{mg} / \mathrm{l}$. The increase over control at $10000 \mathrm{mg} / \mathrm{l}$ was 32.6 , $25.9,27.4,33.3$ and $29.6 \%$ respectively for the same treatments. 
Nevertheless, the highest value of fat content was recorded when treated with glutathione followed by proline, arginine, glutamine and ascorbic acid respectively when using high salinity level (10000 mg/l). These findings are in accordance of the results obtained previously by Parida and Das, (2005) who mentioned that during the onset and development of salt stress within a plant, all the major processes are affected such as photosynthesis, protein synthesis, energy production and lipid metabolism.

Table 12. Effect of proline, ascorbic acid, arginine, glutathione and glutamine on fat content of wheat plants under different salinity levels.

\begin{tabular}{|c|c|c|c|c|}
\hline \multicolumn{5}{|c|}{ Fat content $(\%)$} \\
\hline Treatments & $6000 \mathrm{mg} / \mathrm{l}$ & $8000 \mathrm{mg} / \mathrm{l}$ & $10000 \mathrm{mg} / \mathrm{l}$ & Mean \\
\hline Control* & $1.70 \mathrm{~cd}$ & $1.55 \mathrm{~d}$ & $1.35 \mathrm{e}$ & $1.533 \mathrm{~b}$ \\
\hline Proline & $1.95 \mathrm{a}$ & $1.83 \mathrm{abc}$ & 1.79 abc & $1.857 \mathrm{a}$ \\
\hline Ascorbic acid & $1.90 \mathrm{ab}$ & $1.76 \mathrm{abc}$ & $1.70 \mathrm{~cd}$ & $1.787 \mathrm{a}$ \\
\hline Arginine & $1.88 \mathrm{abc}$ & $1.82 \mathrm{abc}$ & $1.72 \mathrm{bcd}$ & $1.807 \mathrm{a}$ \\
\hline Glutathione & $1.92 \mathrm{ab}$ & $1.81 \mathrm{abc}$ & $1.80 \mathrm{abc}$ & $1.837 \mathrm{a}$ \\
\hline Glutamine & $1.86 \mathrm{abc}$ & $1.78 \mathrm{abc}$ & $1.75 \mathrm{bc}$ & $1.797 \mathrm{a}$ \\
\hline Mean & $1.868 \mathrm{a}$ & $1.758 \mathrm{abc}$ & $1.685 \mathrm{abc}$ & \\
\hline
\end{tabular}

Note: Values have the same letter in the same column are not significantly different at $\quad \mathrm{LSD} \leq 0.05$ level according to Duncan's Multiple Range Test (DMRT). *Wheat plants treated with sea salt only.

Antioxidant enzymes: Analysis of variance (ANOVA) of data presented in Table 13 shows that salt stress significantly increases the catalase activity in leaves of wheat plant compared with untreated plants. The data recorded in the same table indicated that the catalase activity was gradually increased with increasing salinity level. As shown in Table 14 the application of proline, ascorbic acid, arginine, glutathione and glutamine caused a further increase in catalase activity compared with control plants under different salinity level. However the increase of catalase activity over control was 6.3, 
12.5, 25, 56.3 and $25 \%$ when treated with proline, ascorbic acid, arginine, glutathione and glutamine respectively at $6000 \mathrm{mg} / \mathrm{l}$, while the increase over control for the same treatments was 5.6, 8.3, 22.2, 44.4 and $16.7 \%$ respectively at $8000 \mathrm{mg} / \mathrm{l}$. Whereas the increase of catalase activity over control was $2.5,5,15,37.5$ and $20 \%$ respectively at $10000 \mathrm{mg} / \mathrm{l}$ when using the same treatments. Moreover the highest value of catalase activity was recorded when treated with glutathione followed by glutamine, arginine, ascorbic acid and proline respectively when using the highest concentration of sea salt $(10000 \mathrm{mg} / \mathrm{l})$.

Table 13. Effect of salt stress on some antioxidant enzymes of wheat plants.

\begin{tabular}{|l|c|c|c|}
\hline $\begin{array}{c}\text { Parameter } \\
\text { Treatmant }\end{array}$ & APX activity & POX activity & CAT activity \\
\hline \hline control* & $470 \mathrm{a}$ & $95 \mathrm{~d}$ & $23 \mathrm{~d}$ \\
\hline sea salt $6000 \mathrm{mg} / \mathrm{l}$ & $620 \mathrm{~b}$ & $140 \mathrm{c}$ & $32 \mathrm{c}$ \\
\hline sea salt $8000 \mathrm{mg} / \mathrm{l}$ & $675 \mathrm{c}$ & $156 \mathrm{~b}$ & $36 \mathrm{~b}$ \\
\hline sea salt $10000 \mathrm{mg} / \mathrm{l}$ & $735 \mathrm{~d}$ & $171 \mathrm{a}$ & $40 \mathrm{a}$ \\
\hline
\end{tabular}

Note: Effect of different salinity level on Ascorbate peroxidase (APX), peroxidase (POX) and catalase (CAT) activity (unit $\min ^{-1} \cdot \mathrm{g}^{-1} \mathrm{FW}$ ). Values have the same letter in the same column are not significantly different at $L S D \leq 0.05$ level according to Duncan's Multiple Range Test (DMRT). *Wheat plants irrigated with tap water. 
Table 14. Effect of proline, ascorbic acid, arginine, glutathione and glutamine on Catalase activity of wheat plants under different salinity levels.

\begin{tabular}{|c|c|c|c|c|}
\hline \multicolumn{5}{|c|}{ Catalase activity (unit $\mathrm{min}^{-1} \cdot \mathrm{g}^{-1} \mathrm{FW}$ ) } \\
\hline Treatments & $6000 \mathrm{mg} / \mathrm{l}$ & $8000 \mathrm{mg} / \mathrm{l}$ & $10000 \mathrm{mg} / \mathrm{l}$ & Mean \\
\hline Control* & $32 n$ & 361 & $40 \mathrm{I}$ & $36.00 \mathrm{e}$ \\
\hline Proline & $34 \mathrm{~m}$ & $38 \mathrm{k}$ & $41 \mathrm{~h}$ & $37.67 \mathrm{~d}$ \\
\hline Ascorbic acid & 361 & $39 \mathrm{j}$ & $42 \mathrm{~g}$ & $39.00 \mathrm{c}$ \\
\hline Arginine & $40 \mathrm{i}$ & $44 \mathrm{f}$ & $46 \mathrm{e}$ & $43.33 \mathrm{~b}$ \\
\hline Glutathione & $50 \mathrm{c}$ & $52 \mathrm{~b}$ & $55 \mathrm{a}$ & $52.33 \mathrm{a}$ \\
\hline Glutamine & $40 \mathrm{i}$ & $42 \mathrm{~g}$ & $48 \mathrm{~d}$ & $43.33 \mathrm{~b}$ \\
\hline Mean & $38.67 \mathrm{c}$ & $41.83 \mathrm{~b}$ & $45.33 \mathrm{a}$ & \\
\hline
\end{tabular}

Note: Values have the same letter in the same column are not significantly different at LSD $\leq 0.05$ level according to Duncan's Multiple Range Test (DMRT). *Wheat plants treated with sea salt only.

It has been found in the present investigation that, salt stress significantly increases the peroxidase activity in leaves of wheat plant compared with untreated plants. However, peroxidase activity was increased significantly and gradually with increasing salinity levels as shown in Table (13). Moreover, addition of proline, ascorbic acid, arginine, glutathione and glutamine showed significant increases in peroxidase activity compared with control plants under different salinity levels (Table 15). However, peroxidase activity increase over control was $35.7,23.6,40,37.1$ and $42.9 \%$ when treated with proline, ascorbic acid, arginine, glutathione and glutamine respectively at $6000 \mathrm{mg} / \mathrm{l}$, while the increase over control was 26.9, 15.4, $28.2,29.5$ and $33.3 \%$ respectively at $8000 \mathrm{mg} / \mathrm{l}$. Whereas the increase over control was 20, 5.9, 18.8, 22.9 and $23.5 \%$ respectively for the same treatments at $10000 \mathrm{mg} / \mathrm{l}$. Nevertheless, the highest value of peroxidase activity was recorded when treated with glutamine compared with control 
plants followed by glutathione, arginine, proline and ascorbic acid respectively under high salinity condition $(10000 \mathrm{mg} / \mathrm{l})$.

Table 15. Effect of proline, ascorbic acid, arginine, glutathione and glutamine on Peroxidase activity of wheat plants under different salinity levels.

\begin{tabular}{|c|c|c|c|c|}
\hline \multicolumn{5}{|c|}{ Peroxidase activity (unit $\min ^{-1} \cdot \mathrm{g}^{-1} \mathrm{FW}$ ) } \\
\hline Treatments & $6000 \mathrm{mg} / \mathrm{l}$ & $8000 \mathrm{mg} / \mathrm{l}$ & $10000 \mathrm{mg} / \mathrm{l}$ & Mean \\
\hline Control* & $140 \mathrm{o}$ & $156 \mathrm{n}$ & $170 \mathrm{~m}$ & $155.3 \mathrm{f}$ \\
\hline Proline & $190 \mathrm{j}$ & $198 \mathrm{~g}$ & $204 \mathrm{~d}$ & $197.3 \mathrm{~d}$ \\
\hline Ascorbic acid & 1731 & $180 \mathrm{k}$ & $180 \mathrm{k}$ & $177.7 \mathrm{e}$ \\
\hline Arginine & $196 \mathrm{~h}$ & $200 \mathrm{f}$ & $202 \mathrm{e}$ & $199.3 \mathrm{c}$ \\
\hline Glutathione & $192 \mathrm{i}$ & $202 \mathrm{e}$ & $209 \mathrm{~b}$ & $201.0 \mathrm{~b}$ \\
\hline Glutamine & $200 \mathrm{f}$ & $208 \mathrm{c}$ & $210 \mathrm{a}$ & $206.0 \mathrm{a}$ \\
\hline Mean & $181.8 \mathrm{c}$ & $190.7 \mathrm{~b}$ & $195.8 \mathrm{a}$ & \\
\hline
\end{tabular}

Note: Values have the same letter in the same column are not significantly different at LSD $\leq 0.05$ level according to Duncan's Multiple Range Test (DMRT).

Analysis of variance (ANOVA) of data presented in Table 13 shows that salt stress significantly increases the ascorbate peroxidase activity compared with untreated plants, the increment was found to be increased with increasing salt concentrations, particularly at $6000 \mathrm{mg} / \mathrm{l}, 8000 \mathrm{mg} / \mathrm{l}$ and 10000 $\mathrm{mg} / \mathrm{l}$ respectively. However the effect caused by different treatments on ascorbate peroxidase activity was observed by comparing the different treatments with the control as shown in Table 16. The increase over control was $40.3,3.8,11.3,62.6$ and $55.2 \%$ when treated with proline, ascorbic acid, arginine, glutathione and glutamine respectively at $6000 \mathrm{mg} / \mathrm{l}$, while the increase over control was 32.1, 1.2, 1.1, 63.1 and $47.3 \%$ respectively at 8000 $\mathrm{mg} / \mathrm{l}$. Whereas the increase over control was $25.3,5.2,75.8$ and $44.6 \%$ when treated with proline, arginine, glutathione and glutamine respectively at $10000 \mathrm{mg} / \mathrm{l}$ while there was a decrease in ascorbate peroxidase activity for 68 
treatment with ascorbic acid comparing with control plants. Moreover the highest value of ascorbate peroxidase activity was recorded when treated with glutathione compared with control plants followed by glutamine, proline, arginine and ascorbic acid respectively when using high salinity level (10000 $\mathrm{mg} / \mathrm{l})$.

Table 16. Effect of proline, ascorbic acid, arginine, glutathione and glutamine on Ascorbate Peroxidase activity of wheat plants under different salinity levels.

\begin{tabular}{|c|c|c|c|c|}
\hline \multicolumn{5}{|c|}{ Ascorbate peroxidase activity (unit $\min ^{-1} \cdot \mathrm{g}^{-1} \mathrm{FW}$ ) } \\
\hline Treatments & $6000 \mathrm{mg} / \mathrm{l}$ & $8000 \mathrm{mg} / \mathrm{l}$ & $10000 \mathrm{mg} / \mathrm{l}$ & Mean \\
\hline Control* & $620 \mathrm{~h}$ & $675 \mathrm{~h}$ & $735 \mathrm{fgh}$ & $676.7 \mathrm{~d}$ \\
\hline Proline & 870 defg & 892 cdef & 921 bcde & $894.3 \mathrm{bc}$ \\
\hline Ascorbic acid & $650 \mathrm{~h}$ & 683 efgh & $720 \mathrm{fgh}$ & $706.6 \mathrm{~d}$ \\
\hline Arginine & $690 \mathrm{gh}$ & 747 efgh & 773 efgh & $736.7 \mathrm{~cd}$ \\
\hline Glutathione & $1008 \mathrm{bcd}$ & $1101 \mathrm{~b}$ & $1292 \mathrm{a}$ & $1211 \mathrm{a}$ \\
\hline Glutamine & $962 \mathrm{bcd}$ & $994 \mathrm{bcd}$ & $1063 \mathrm{bc}$ & $1006 \mathrm{~b}$ \\
\hline Mean & $800 \mathrm{a}$ & $859.2 \mathrm{a}$ & $956.2 \mathrm{a}$ & \\
\hline
\end{tabular}

Note: Values have the same letter in the same column are not significantly different at $\mathrm{LSD} \leq 0.05$ level according to Duncan's Multiple Range Test (DMRT). *Wheat plants treated with sea salt only

The higher activities of ascorbate peroxidase of wheat plants were in agreement with those reported by Mandhania et al., (2006), who concluded that under salinity stress, the stimulation of ascorbate peroxidase activity was much higher in salt-tolerant than those of salt-sensitive cultivar. These results could interpret that salt tolerance of cultivar sakha 93 seems to be linked with increase in the activity of antioxidant enzymes. The salt-induced enhancement of catalase activity in wheat plants indicated that it had a higher capacity for the decomposition of $\mathrm{H}_{2} \mathrm{O}_{2}$ generated by SOD. Thus, catalase activity coordinated with SOD activity can represent a central protective role 
in the $\mathrm{O}_{2}^{-}$and $\mathrm{H}_{2} \mathrm{O}_{2}$ scavenging process, also catalase is the main scavenger of strong oxidant $\mathrm{H}_{2} \mathrm{O}_{2}$ in peroxisomes and it converts $\mathrm{H}_{2} \mathrm{O}_{2}$ to water and molecular oxygen (Bahari et al., 2013). Plants have several antioxidant strategies like ROS-scavenging enzymes such as peroxidases and catalases response to salt stress (Rea et al., 2004; Aronova et al., 2005). Generally, the increases of catalase activity are a strategy for improving salt tolerance (Vaidyanathan et al., 2003). The active involvement of these enzymes is related, at least in part, to salt-induced oxidative stress tolerance in wheat plant. Also like catalase the peroxidase plays a vital role in plant defense against oxidative stress by scavenging $\mathrm{H}_{2} \mathrm{O}_{2}$ in chloroplast, cytosol, mitochondria and peroxisome of plant cells (Asada, 2006). Similar finding were reported by Bartels and Hussain, (2008) who found that peroxidase and catalase activity were increased in response to salinity. Moreover, Treatment application of ascorbic acid had a stimulating effect on some oxidative enzymes of wheat plants. These increases were concurrently with increasing protein levels indicating that vitamins could alleviate the inhibitory effects of salt stress by enhancing protein synthesis, as vitamins might act as activators for protein synthesis. Also, Padh, (1990) reported that ascorbic acid plays an important role in preserving the activities of enzymes that contain prosthetic transition metal ions. Ascorbic acid acts as a primary substrate in cyclic pathway for enzyme detoxification of hydrogen peroxide (Shalata and Neumann 2001). In conclusion, it can be concluded that treatment application of ascorbic acid can reduce the harmful effects of ROS and improves plant resistant under salt stress conditions. However, In our study, application of 
ascorbic acid significantly increase activity of antioxidant enzymes such as catalase, peroxidase and ascorbate peroxidase of wheat plant compared with control under different salinity levels. These results are in good agreement with those of Shalata and Neumann (2001) who found that catalase and peroxidase activities increased in tomato plants treated with ascorbic acid under salt stress. Similar responses were reported by Yan et al., (2000) and Hua and Guo, (2002), they observed that Proline application lead to the increase production of ascorbate peroxidase and peroxidase in salt stressed Glycine max plants. Also Seki et al., (2007), Sharma and Dietz, (2006) and Simon-Sarkadi et al., $(2005,2006)$ stated that exogenous polyamine increases activity of peroxidase and catalase, along with proline production. In conclusion, several studies have shown that polyamine accumulation occurs under salinity stress (Groppa and Benavides, 2008; Pang et al., 2007). Hence, high cellular levels of polyamines (PAs) correlate with plant tolerance in a wide array of environmental stresses. However, the physiological significance of polyamine (PA) accumulation remains elusive and must be revealed whether these responses are due to stress-induced injury or a protective response to abiotic stress. Alternative approaches also include the use of PA as an external application which can also be administered for increasing tolerance to various stresses. In the long run, PA can be exploited in the same way as farm chemicals to mitigate stress-induced injury for crop protection. However, evidence from field level studies is still lacking. Some striking evidences of exogenous application of PA to counteract environment stresses are expected to promote its extended application to other crops (Hussein et al., 2011). 


\section{REFERENCES}

Aebi, H. (1984). Catalase in vitro. Methods in enzymology, 105, 121-126.

Afzal, I., Basra, S. M., Farooq, M. \& Nawaz, A. (2006). Alleviation of salinity stress in spring wheat by hormonal priming with $\mathrm{ABA}$, salicylic acid and ascorbic acid. Int. J. Agric. Biol, 8(1), 23-28.

Ali, Q., Ashraf, M. \& Athar, H. R. (2007). Exogenously applied proline at different growth stages enhances growth of two maize cultivars grown under water deficit conditions. Pak. J. Bot., 39(4), 1133 1144.

Asada, K. (2006). Production and scavenging of reactive oxygen species in chloroplasts and their functions. Plant Physiology, 141, 391-396.

Ashraf, M. \& Ahmad, S. (2000). Influence of sodium chloride on ion accumulation, yield components and fibre characteristics in salttolerant and salt-sensitive lines of cotton (Gossypium hirsutum L.). Field Crops Research, 66(2), 115-127.

Ashraf, M. \& Foolad, M. (2007). Roles of glycine betaine and proline in improving plant abiotic stress resistance. Environmental and Experimental Botany, 59(2), 206-216.

Bahari, A., Pirdashti, H. \& Yaghubi, M. (2013). The effects of amino acid fertilizers spraying on photosynthetic pigments and antioxidant enzymes of wheat (Triticum aestivum L.) under salinity stress. International Journal of Agronomy and Plant Production, 4(4), 787-793.

Balbaa, L. K. (2002). Physiological effect of ascorbic acid and kinetin on growth and chemical constituents of Tagets minuta L. J. Appl. Sci. Egypt, 17, 249-267.

Braun, H. J., Atlin, G. \& Payne, T. (2010). Multi-location testing as a tool to identify plant response to global climate change. Climate change and crop production, 115-138. 
Cabo, R. C., Gonza-lez-Reyes, J. A., Cordoba, F. \& Navas, P. (1996). Rooting hastened in onions by ascorbate and ascorbate free radical. J. Plant Growth Regul., 15, 53-56.

Citterio, S., Sgorbati, S., Scippa, S. \& Sparvoli, E. (1994). Ascorbic acid effect on the onset of cell proliferation in pea root. Physiol. Plant., 92, 601-607.

Claussen, W. (2005). Proline as a measure of stress in tomato plants. Plant Science, 168(1), 241-248.

Colmer, T. D., Flowers, T. J. \& Munns, R. (2006). Use of wild relatives to improve salt tolerance in wheat. Journal of Experimental Botany, 57(5), 1059-1078.

Couee, I., Hummel, I., Sulmon, C., Gouesbet, G. \& El-Amrani, A. (2004). Involvement of polyamines in root development. Netherlands, 76 (1), 1-10.

Ekmekçi, B. A. \& Karaman, M. (2012). Exogenous ascorbic acid increases resistance to salt of Silybum marianum (L.). African Journal of Biotechnology, 11 (42), 9932-9940.

El-Bagoury, H. A., Hossni, Y. A., El-Tantawy, A., Shehata, M. \& Asmaael, R. (1999). Effect of saline water irrigation on growth and chemical composition of (Casuarina equisetifolia L.) seedlings. Egypt. J. Hort., 26, 47-57.

El-Bassiouny, H. M. S., Mostafa, H. A., El-Khawas, S. A., Hassanein, R. A., Khalil, S. I. \& Abd El-Monem, A. A. (2008). Physiological responses of wheat plant to foliar treatments with arginine or putrescine. Austr. J. of Basic and Applied Sci., 2(4), 1390-1403.

Fayed, T. A. (2010). Effect of some antioxidants on growth, yield and bunch characteristics of Thempson seedless grapevine. American Eurasian J. Agric. and Environmental Sci., 8(3), 322-328.

Fulda, S., Mikkat, S., Stegmann, H. \& Horn, R. (2011). Physiology and proteomics of drought stress acclimation in sunflower (Helianthus annuus L.). Plant Biology, 13(4), 632-642.

Ghassemi-Golezani, K., Nikpour-Rashidabad \& Zehtab-Salmasi, S. (2012). Physiological performance of pinto bean cultivars under salinity. 
International Journal of Plant, Animal and Environmental Sciences, 2, 223-228.

Giri, J. (2011). Glycinebetaine and abiotic stress tolerance in plants. Plant Signal Behav., 6, 1746-1751.

Gonzalez-Aguilar, G. A., Zacarias, L., Mulas, M. \& Lafuente, M. T. (1997). Temperature and duration of water dips influence chilling injury, decay and polyamine content in Fortune mandarins Postharvest. Biol. Technol., 12, 61-69.

Gorham, J. (1994). Salt tolerance in the Triticeae: K/Na discrimination in some perennial wheatgrasses and their amphiploids with wheat. Journal of Experimental Botany, 45(4), 441-447.

Hellal, F. A., Abdelhameid, M., Doaa M., Abo-Basha \& Zewainy, R. M. (2012). Alleviation of the adverse effects of soil salinity stress by foliar application of silicon on faba bean (Vica faba L.). Journal of Applied Sciences Research, 8(8), 4428-4433.

Hossain, H., Rahman, M. A., Alam, M. S. \& Singh, R. K. (2015). Mapping of quantitative trait loci associated with reproductive-stage salt tolerance in rice. Journal of Agronomy and Crop Science, 201(1), 17-31.

Hozayn, M., Abd El-Monem, A. A., Ebtihal, M. \& Amira, M. S. (2013). Amelioration of salinity stress in mungbean (Vigna radiata L.) plant by soaking in arginine. Journal of Applied Sciences Research, 9(1), 393-401.

HuiGuo, D., Shu, Y., WenJuan, L., DeHui, X., DongHong, Q., HouGuo, 1. \& HongHui, L. (2006). Effects of exogenous spermidine on photosystem II of wheat seedlings under water stress. Journal of Integrative Plant Biology, 48(8), 920-927.

Hussein, K. A., Hassan, A. F. \& El-Nagar, G.Y. (2008). Influence of irrigation with saline water on yield and nutrients uptake of wheat plant grown in sandy andsandy loam soils. Alex. Sci. Exch., 29, 55-63. 
Hussein, M. M., Abd El-Rheem, Kh. M., Khaled, S. M. \& Youssef, R. A. (2011). Growth and nutrients status of wheat as affected by ascorbic acid and water salinity. Nature and Science, 9(10), 6469.

Jaleel, C. A., Manivannan, M., Wahid, A., Farooq, M., Al-Juburi, H. J., Somasundaram, Y. \& Panneerselvam, R. (2009). Drought stress in plants: a review on morphological characteristics and pigments composition. Int. J. Agric. Biol., 11(1), 100-105.

Karima, M. Gamal El-Din \& Abdel-Wahed, M. S. A. (2005). Effect of some amino acids on growth and essential oil content of chamomile plant. Int. J. Agric. Biol., 7(3), 376-380.

Khan, M. A., Qayyum, A. \& Noor, E. (2007). Assessment of wheat genotypes for salinity tolerance. In 8th African Crop Science Society Conference pp. 75-78. African Crop Science Society.

Khan, W., Prithiviraj, B. \& Donald, S. L. (2003). Photosynthetic responses of corn and soybean to foliar application of salicylates. J. Plant Physiol., 160, 485-92.

Khatkar, D., \& Kuhad, M. S. (2000). Short-term salinity induced changes in two wheat cultivars at different growth stages. Biologia Plantarum, 43(4), 629-632.

Kong-ngern, K., Bunnag, S. \& Theerakulpisut, P. (2012). Proline, hydrogen peroxide, membrane stability and antioxidant enzyme activity as potential indicators for salt tolerance in rice (Oryza sativa L.). International Journal of Botany, 8(2), 54.

Kranner, I. \& Seal, C. E. (2013). Salt stress, signalling and redox control in seeds. Functional Plant Biology, 40(9), 848-859.

Krishnamurthy, R. (1991). Amelioration of salinity effect in salt tolerant rice (Oryza sativa L.) by foliar application of putrescine. Plant Cell Physiol., 32, 699-703.

Kumar, K. K., Vidyasaar, R. \& Rao, K. (1988). Studies on growth and activity of photosynthetic enzymes on sorghum bicolor L. as influenced by micronutrients. Proc. indian Nat., Sci., Acard part BBiol. Sci., 54, 75-80. 
Kusvuran, S., Ellialtioglu, S., Yasar, F. \& Abak, K. (2012). Antioxidative enzyme activities in the leaves and callus tissues of salt-tolerant and salt-susceptible melon varieties under salinity. African Journal of Biotechnology, 11(3), 635-641.

Lixiong, H., Nada, K. \& Tachibana, S. (2002). Effects of spermidine pretreatment through the roots on growth and photosynthesis of chilled cucumber plants Cucumber sativus L. J. Japan. Soc. Hort. Sci., 71, 490-498.

Maksoud, M. A., Saleh, M. A., El-Shamma, M. S. \& Fouad, A. A. (2009). The beneficial effect of biofertilizers and antioxidants on olive trees under calcareous soil conditions. World J. of Agri. Sci, 5(3), $350-352$.

Mandhania, S., Madan, S. \& Sawhney, V. (2006). Antioxidant defense mechanism under salt stress in wheat seedlings. Biologia Plantarum, 50(2), 227-231.

Maqsood, T., Akhtar, J., Farooq, M. R., Haq, M. A. \& Saqib, Z. A. (2008). Biochemical attributes of salt tolerant and salt sensitive maize cultivars to salinity and potassium nutrition. Pak. J. Agri. Sci., 45, $1-5$.

Munir, N. \& Aftab, F. (2011). Enhancement of salt tolerance in sugarcane by ascorbic acid pretreatment. African Journal of Biotechnology, 10(80), 18362-18370.

Munns, R. (2002). Comparative physiology of salt and water stress. Plant cell and environment, 25(2), 239-250.

Munns, R. (2005). Genes and salt tolerance: bringing them together. New phytologist, 167(3), 645-663.

Nasibi, F., Yaghoobi, M. M. \& Kalantari, K. M. (2011). Effect of exogenous arginine on alleviation of oxidative damage in tomato plant underwater stress. Journal of Plant Interactions, 6(4), 291-296.

Nasibi, F., Kalantari, K. M. \& Barand, A. (2014). Effect of seed pre-treatment with L-arginine on improvement of seedling growth and 
alleviation of oxidative damage in canola plants subjected to salt stress. Iran J. Plant Physiol., 5(1), 1217-24.

Nassar, A. H., El-Tarabily K. A. \& Sivasithamparam, K. (2003). Growth promotion of bean (Phaseolus vulgaris L.) by a polyamine producing isolate of Streptomyces grisoluteus. Plant Growth Regul. Kluwer Academic Publisher, Dordecht, Netherlands, 40 (2), 97-106.

Nissen, O. (1983). MSTAT-C: A microcomputer program for the design, management, and analysis of agronomic research experiments. Michigan State University, East Lansing, Michigan, USA.

Padh, H. (1990). Cellular function of ascorbic acid. Biochemistry and Cell Biology, 68, 1166-1173.

Parida, A. \& Das, A. B. (2005). Salt tolerance and salinity effects on plants: a review Original Research Article. Ecotoxicology and Environmental Safety, 60 (3), 324-349.

Polle, A., Otter, T. \& Seifert, F. (1994). Apoplastic peroxidases and lignification in needles of Norway spruce (Picea abies L.). Plant Physiology, 106(1), 53-60.

Salam, A., Hollington, P. A., Gorham, J., Jones, R. G. \& Gliddon, C. (1999). Physiological genetics of salt tolerance in wheat (Triticum aestivum L.): performance of wheat varieties, inbred lines and reciprocal F1 hybrids under saline conditions. Journal of Agronomy and Crop Science, 183(3), 145-156.

Salama, K. H. (2009). Amelioration of NaCl-induced alterations on the plasma membrane of Allium cepa $\mathrm{L}$. by ascorbic acid. Australian Journal of Basic and Applied Sciences, 3(2), 990-994.

Shahzad, A., Ahmad, M., Iqbal, M., Ahmed, I. \& Ali, G. M. (2012). Evaluation of wheat landrace genotypes for salinity tolerance at vegetative stage by using morphological and molecular markers. Genetics and Molecular Research, 11(1), 679-692.

Shahzad, A., Iqbal, M., Asif, M., Hirani, A. H. \& Goyal, A. (2013). Growing wheat on saline lands: can a dream come true?. Australian Journal of Crop Science, 7(4), 515. 
Shalata, A. \& Neumann, P.M. (2001). Exogenous ascorbic acid (Vitamin C) increases resistance to stress and reduces lipid peroxidation. Journal of Experimental Botany, 52, 2207-2221.

Sharkey, T. D., Carl, J. B., Graham, D. F. \& Singsaas, E. L. (2007). Fitting photosynthetic carbon dioxide response curves for $\mathrm{C} 3$ leaves. Plant Cell Environ., 30, 1035-1040.

Sheteaw, S. A. (2007). Improving growth and yield of salt-stressed soybean by exogenous application of jasmonic acid and ascobin. Int. J. Agric. Biol., 9 (3), 473-478.

Silveira, J. A. G., Melo, A. R. B., Viegas, R. A. \& Oliveira, J. T. A. (2001). Salinity-induced effects on nitrogen assimilation related to growth in cowpea plants. Environmental and Experimental Botany, 46(2), 171-179.

Taffouo, V. D., Kouamou, J. K., Ngalangue, L. M. T., Ndjeudji, B. A. N. \& Akoa, A. (2009). Effects of salinity stress on growth, ions partitioning and yield of some cowpea (Vigna unguiculata L. Walp.) cultivars. International Journal of Botany, 5(2), 135-143.

Taffouo, V. D., Kenne, M., Tasse, R. F., Fotsop, W. O., Fonkou, T., Vondo, Z. \& Amougou, A. (2004). Salt stress variation response in five leguminous plants. Agron. Afr., 16, 33-44.

Talaat, N. B. (2003). Physiological studies on the effect of salinity, ascorbic acid and putrescine of sweetpepper plant. Ph.D. Thesis , Fac. Agric., Cairo Univ., Egypt.

Türkan, I., Bor, M., Özdemir, F. \& Koca, H. (2005). Differential responses of lipid peroxidation and antioxidants in the leaves of droughttolerant $P$. acutifolius Gray and drought-sensitive $P$. vulgaris $\mathrm{L}$. subjected to polyethylene glycol mediated water stress. Plant Science, 168(1), 223-231.

Vaidyanathan, H., Sivakumar, P., Chakrabarsty, R. \& Thomas, G. (2003). Scavenging of reactive oxygen species in $\mathrm{NaCl}-$ Stressed rice (Oryza sativa L.) differential response in salt-tolerant and sensitive varieties. Plant Science, 165(6), 1411-1418. 
Van Breusegem, F. \& Dat, J. F. (2006). Reactive oxygen species in plant cell death. Plant physiology, 141(2), 384-390.

Verma, S. \& Mishra, S. N. (2005). Putrescine alleviation of growth in salt stressed Brassica juncea by inducing antioxidative defense system. Journal of plant physiology, 162(6), 669-677.

Wang, W. B., Kim, Y. H., Lee, H. S., Kim, K. Y., Deng, X. P. \& Kwak, S. S. (2009). Analysis of antioxidant enzyme activity during germination of alfalfa under salt and drought stresses. Plant Physiology and Biochemistry, 47(7), 570-577.

Xue, Y. F. \& Liu, Z. P. (2008). Antioxidant enzymes and physiological characteristics in two Jerusalem artichoke cultivars under salt stress. Russian journal of plant physiology, 55(6), 776-781.

Yasar, F., Kusvuran, S. \& Ellialtioglu, S. (2006). Determination of antioxidant activities in some melon (Cucumis melo L.) varieties and cultivars under salt stress. The Journal of Horticultural Science and Biotechnology, 81(4), 627-630.

Yoshimura, K., Yabuta, Y., Ishikawa, T. \& Shigeoka, S. (2000). Expression of spinach ascorbate peroxidase isoenzymes in response to oxidative stresses. Plant physiology, 123(1), 223-234.

Youssef, A. Iman, A. \& Talaat, M. (2003). Physiological response of rosemary plants to some vitamins. Egypt. Pharm. J., 1, 81-93.

Zadeh, H. M. \& Naeini, M. B. (2007). Effects of salinity stress on the morphology and yield of two cultivars of canola (Brassica napus L.). J. Agron., 6, 409-414.

Zeid, I. M. (2009). Effect of arginine and urea on polyamines content and growth of bean under salinity stress. Acta physiologiae plantarum, 31(1), 65-70. 


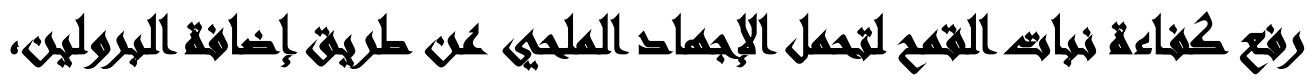

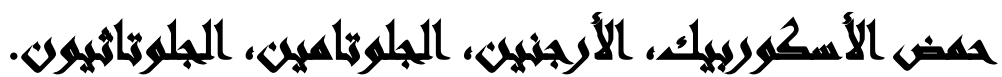

$[r]$

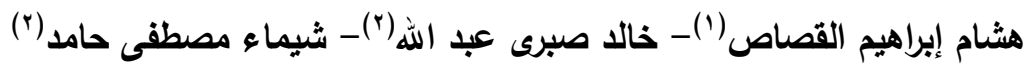

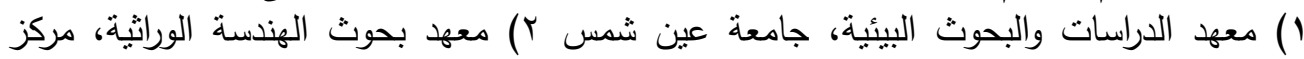
البحوث الزراعية

\section{المستطلس}

اشتملت هذه الدراسه على بعض المركبات التي لها دور في تحسين تحمل النبات للاجهاد

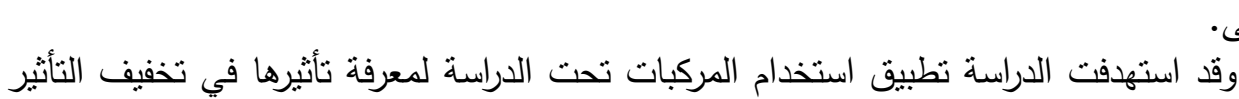
السلبى للملوحة على نباتات القمح. حيث تم تصميم تجربة لمعرفة تأثثر بعض المركبات متمثلة فى البرولين، الأرجنين، الجلوتاثيون،

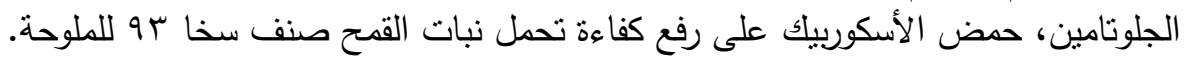

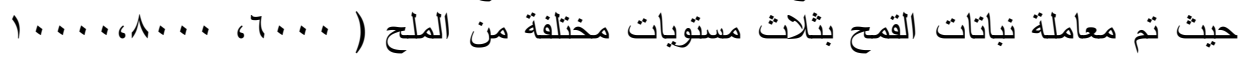

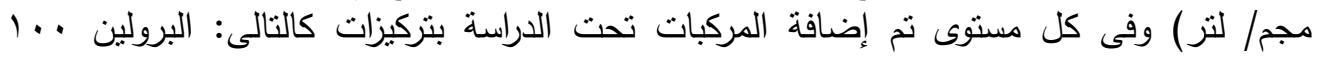

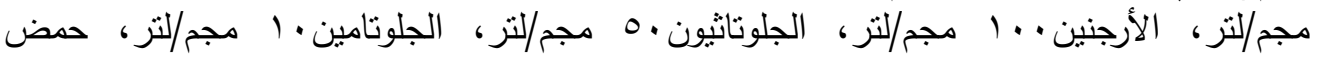

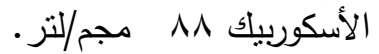
وكانت أهم الننائج المتحصل عليها كالتالى: • تم إثبات الثأثيرات السلبية للتركيزات المرتفعة من ملح البحر على نباتات القمح حيث أدت إلى

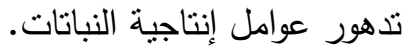
• تم إثبات التأثيرات الإيجابية للمركبات تحت الدراسة حيث أدث إلى تحسين عوامل إنتاجية النباتات

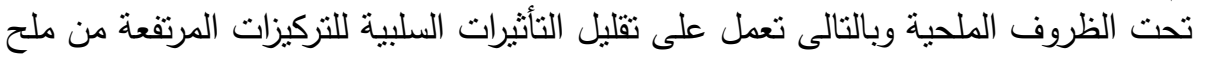
البحر 